Environmental Restoration Division ORNL Environmental Restoration Program

\title{
Data Base Management Plan for the Remedial Investigation of Waste Area Grouping 5 at Oak Ridge National Laboratory, Oak Ridge, Tennessee
}

Date Issued-July 1992

Prepared by

Bechtel National, Inc.

Oak Ridge, Tennessee

under subcontract 30B-99053C

Prepared for

U.S. Department of Energy

Office of Ervironmental Restoration and Waste Management under budget and reporting code EW 20

OAK RIDGE NATIONAL LABORATORY

Oak Ridge, Tennessee 37831-6285 managed by

MARTIN MARIETTA ENERGY SYSTEMS, INC.

for the

U.S. DEPARTMENT OF ENERGY

under contract DE-AC05-84OR21400

DISTPIBUTION OF THIS DOCUMENT IS UNLIMITED 


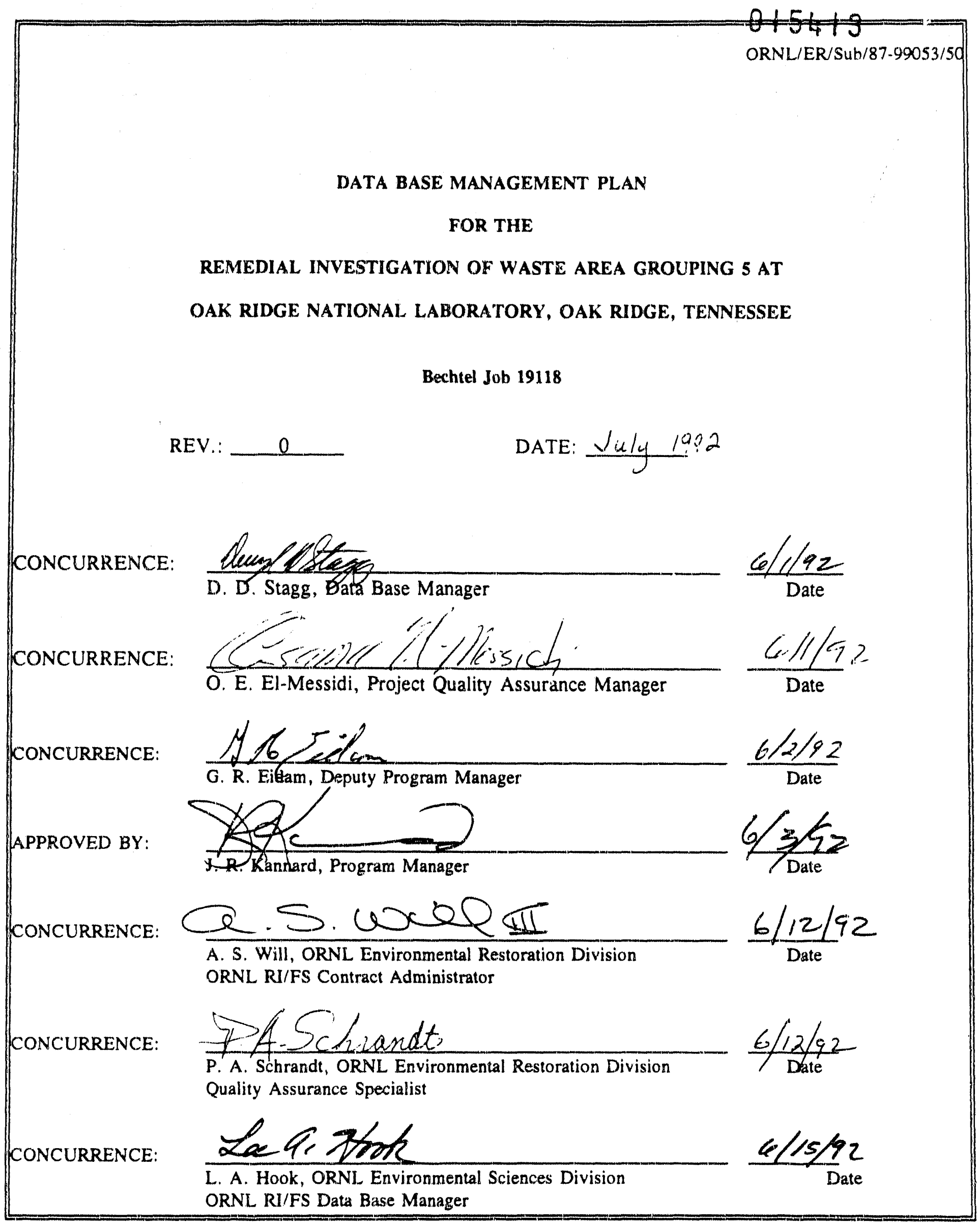




\title{
CONTENTS
}

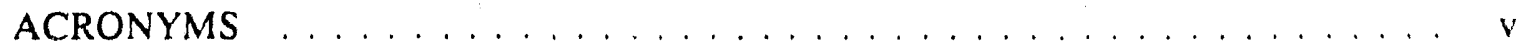

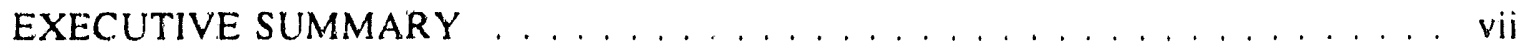

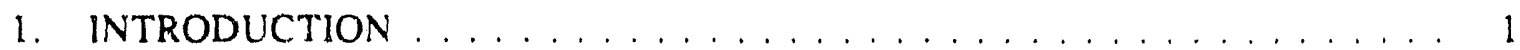

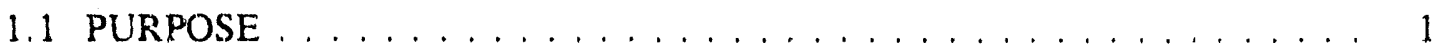

1.2 BACKGROUND $\ldots \ldots \ldots \ldots \ldots \ldots \ldots$

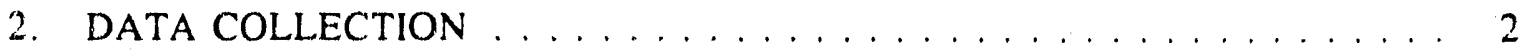

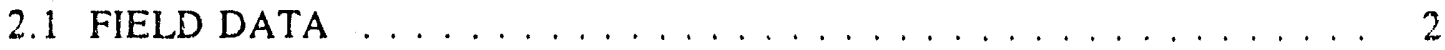

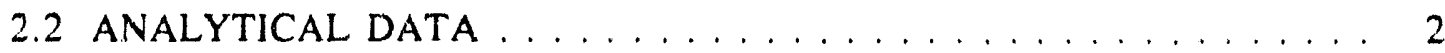

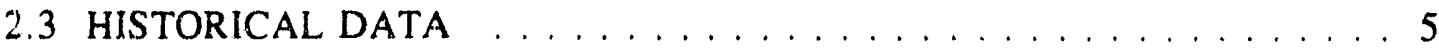

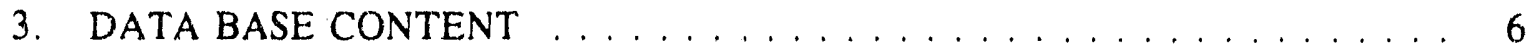

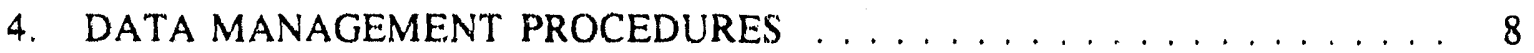

REFERENCES AND PERTINENT PROJECT PROCEDURES . . . . . . . . . . 9

\section{DISCLAIMER}

\begin{abstract}
This report was prepared as an account of work sponsored by an agency of the United States Government. Neither the United States Gnvernment nor any agency thereof, nor any of their employees, makes any warranty, express or implied, or assumes any legal liability or responsibility for the accuracy, completeness, or usefulness of any information, apparatus, product, or process disclosed, or represents that its use would not infringe privately owned rights. Reference herein to any specific commercial product, process, or service by trade name, trademark, manufacturer, or otherwise does not necessarily constitute or imply its endorsement, recommendation, or favoring by the United States Government or any agency thereof. The views and opinions of authors expressed herein do not necessarily state or reflect those of the United States Government or any agency thereof.
\end{abstract}




\section{ACRONYMS}

$\begin{array}{ll}\text { NHF } & \text { New Hydrofracture Facility } \\ \text { OHF } & \text { Old Hydrofracture Facility } \\ \text { OREIS } & \text { Oak Ridge Environmental Information System } \\ \text { ORNL } & \text { Oak Ridge National Laboratory } \\ \text { PDCC } & \text { Project Document Control Center } \\ \text { PP } & \text { BNI project procedure } \\ \text { RI/FS } & \text { remedial investigation/feasibility study } \\ \text { SWSA } & \text { solid waste storage area } \\ \text { TRU } & \text { transuranic } \\ \text { USRADS } & \text { Ultrasonic Ranging and Data Systems } \\ \text { WAG } & \text { waste area grouping }\end{array}$




\section{EXECUTIVE SUMMARY}

This Data Base Management Plan describes the gathering, verifying, analyzing, reporting, and archiving of data generated during Bechtel's remedial investigation of Waste Area Grouping 5. This investigation will produce data documeni ing surficial surveys, geophysical surveys, geologic and hydrologic logs, aquifer tests. watel level measurements, geophysical logs, and stream and seep flow measurements. Also, laboratory analyses will be performed on soil, surface water, groundwater, and sediment samples.

The 1500 series of Bechtel project procedures, "Data Base Management," and the project Data Base Management Plan will be used to ensure that data are handled properly. 


\section{INTRODUCTION}

\subsection{PURPOSE}

The remedial investigation ( $R I$ ) for Waste Area Grouping (WAG) 5 will involve gathering, verifying, analyzing, reporting, and archiving numerous types of field and analytical data. Field investigations will produce data documenting surficial and geophysical surveys, geologic and hydrogeologic logs, aquifer tests, water level measurements, geophysical logs, and stream and seepage flow measurements. Laboratory analyses will be performed on soil, surface water, groundwater, and sediment samples collected during field investigations. All data resulting from these activities will be contained in the Bechtel $\mathrm{RI} /$ feasibility study (FS) project data base and will be managed in accordance with the RI/FS Data Base Management Plan and this WAG-specific plan.

\subsection{BACKGROUND}

During the 40 years of production, operation, and research activities at Oak Ridge National Laboratory (ORNL), various radioactive and hazardous wastes have been generated and disposed of both on site and off site. Waste disposal methods have included shallow land burial in selected areas in Solid Waste Storage Area (SWSA) 5 using trenches and auger holes, above- and below-ground retrievable storage of transuranic (TRU) waste in the TRU Waste Storage Area, and hydraulic fracturing of subsurface geologic formations for liquid and sludge waste disposal at the Old and New Hydrofracture Facilities (OHF and NHF). WAG 5 facilities have been involved in the progressive development of disposal operations at ORNL.

WAG 5 is composed of four main areas: SWSA 5, TRU Waste Storage Area, OHF, and NHF (Fig. 1.1). SWSA 5 and selected areas within the TRU Waste Storage Area were used as waste burial areas from 1959 to 1973. The TRU Waste Storage Area has also been used for the retrievable storage of TRU waste since 1970. In addition to SWSA 5, WAG 5 contains surface facilities, buildings, tanks, sludge basins, and leak sites associated with OHF and NHF. 


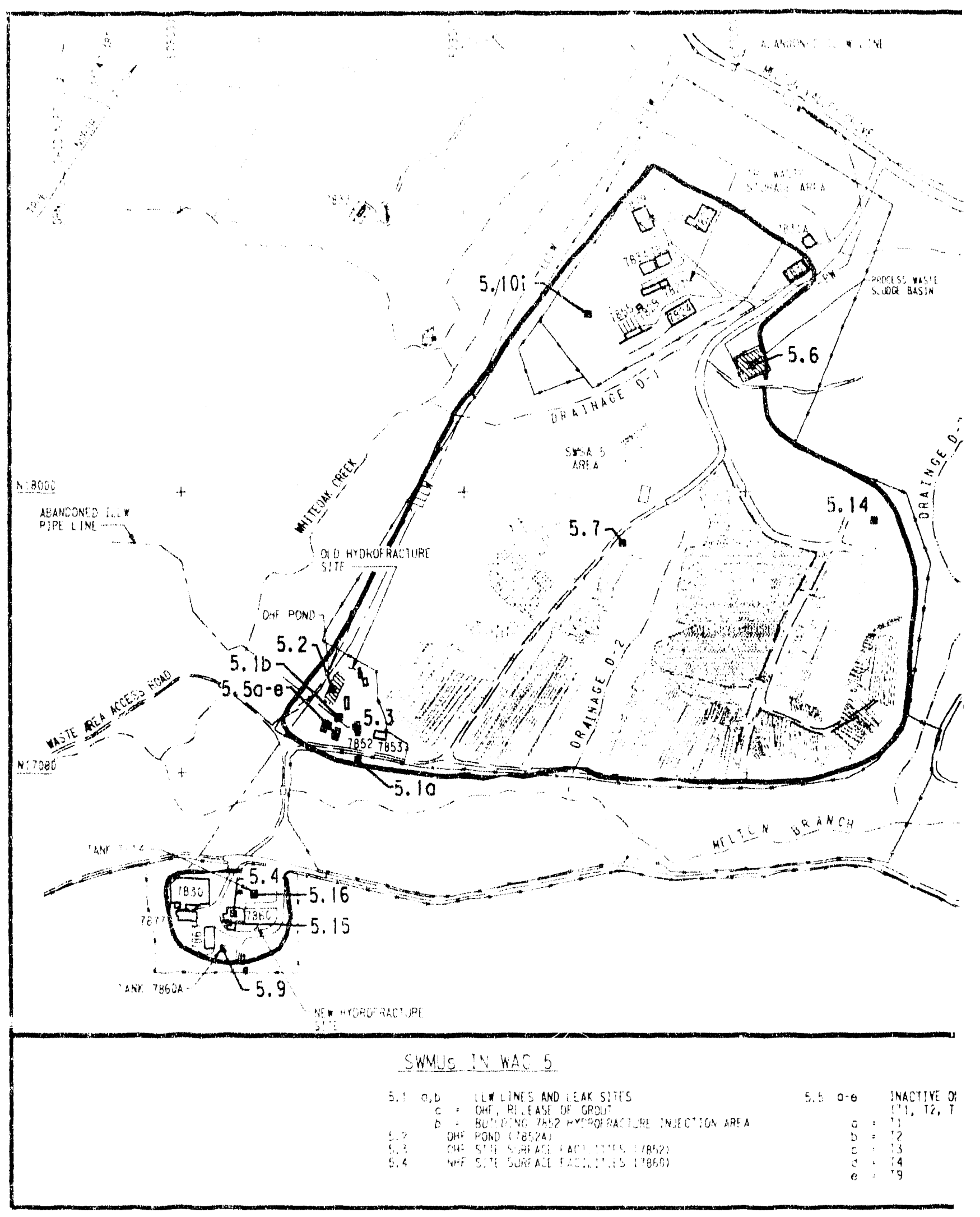

Fig. 1.1. Map showing I 
be documented on the hard copy, and appropriate qualification and validation codes - ill be entered into the electronic file. Complete, validated data packages and data files will be verified by comparing the electronic results file against the hard copy containing validation codes. Validated files will replace the original, unvalidated data in the comprehensive analytical results Oracle table (CON101 in PP 1501.1). Validated data packages will also be retained in the Project Document Control Center (PDCC). Error checking and completeness verification will be performed on all data replacements.

\subsection{HISTORICAL DATA}

Data transferred to Bechtel's data base from ORNL's existing data base will be verified according to PP 1502 and stored in an Oracle table prior to use by project personnel. Merging of ORNL and Bechtel data will be performed as necessary and according to appropriate data types defined in PP 1501.1. This merging will be done whenever combined data are to be used in producing technical documents or their associated risk assessments, characterization summaries, models, etc. Merged files will be supplied to the Oak Ridge Environmental information System (OREIS) according to WAG-specific schedules (i.e., during submittal of technical memorandums). 


\section{DATA BASE CONTENT}

Anticipated sources of daca associated with WAG 5 field and laboratory activities are listed by data type code in Table 3.1. Full data base content and format listing for each data type can be found in PP 1501.1: master tables defining coded values for various data fields are given in PP 1501 .

Engineering applications using the data base, particularly figures generated for reports, will use data resident in project data base tables. Data will be transferred to graphics workstations either in ASCII or Oracle format.

Bechtel's drawing 99-SK-01, "Overall Sampling Task Process Flowchart," illustrates data collection and transfer throughout RI/FS activities. Table 3.1 lists specific data types associated with anticipated field investigations relevant to scheduled WAG 5 activities. 
Table 3.1. WAG 5 data base contents

\begin{tabular}{|c|c|c|}
\hline Data type & Data type code & Responsible group \\
\hline $\begin{array}{l}\text { Civil survey } \\
\text { Topographic maps } \\
\text { Structures and foundations } \\
\text { Well/piezometer location and elevation } \\
\text { Sampling point location }\end{array}$ & $\begin{array}{l}\text { SSV101 } \\
\text { SSV103 } \\
\text { SSV104 } \\
\text { SSV105 }\end{array}$ & Engineering \\
\hline $\begin{array}{l}\text { Surface radiation and dose rates } \\
\text { USRADS }\end{array}$ & SSV403 & Engineering \\
\hline $\begin{array}{l}\text { Geophysical surveys } \\
\text { Electromagnetic ground conductivity } \\
\text { Magnetometer } \\
\text { Pipe location } \\
\text { Seismic refraction }\end{array}$ & $\begin{array}{l}\text { SSV201/201A } \\
\text { SSV202/202A } \\
\text { SSV203 } \\
\text { SSV301 }\end{array}$ & Geotechnical \\
\hline $\begin{array}{l}\text { Boring and well data } \\
\text { Geologic/drilling log } \\
\text { Well construction } \log \\
\text { Well development log } \\
\text { Geophysical well log }\end{array}$ & $\begin{array}{l}\text { HYG101 } \\
\text { HYG102/102A } \\
\text { HYG103 } \\
\text { HYG105 }\end{array}$ & Geotechnical \\
\hline Aquifer tests & HYG201 & Geotechnical \\
\hline Field water level measurements & HYG301/301A & Geotechnical \\
\hline Groundwater sampling record & HYG701 & Geotechnical \\
\hline Stream flow & HYL101 & Modeling \\
\hline Seepage flow & HYL201 & Modeling \\
\hline Radionuclide and chemical data & CON101 & Analytical \\
\hline
\end{tabular}




\section{DATA MANAGEMENT PROCEDURES}

Bechtel's RI/FS data base for WAG 5 will be compatible with OREIS. All environmental data will be stored in Oracle tables and will be converted to SAS or Oracle export formats as necessary for transfer to OREIS. Supporting documentation to provide an audit trail for tracking environmental data base content will be stored in PDCC. Documentation will include data collection, transfer, change request, and validation forms. Raw data can be in a number of formats, including bar code reader files, laboratory and field instrumentation log files, spreadsheets, and a variety of encrypted (software-dependent) coded files. Project personnel health and safety information, document control, laboratory sample analysis tracking, engineering, and project management data bases are maintained by the respective functional departments and are explained in individual project procedures and in the project Data Base Management Plan. Data received from ORNL will be tracked by PDCC and included in project data base tables as explained in Sect. 2.3.

Access to data is controlled by procedures found in PP 1501. Verified data $c . n$ be changed (and changes tracked and approved) by use of "Data Base Change Request" forms. The individual making the request will not make the change. Similarly, data can be output only when approved "Data Base Request for Services" forms are submitted and processed.

Field sample collection and handling are controlled by PPs 1603, 1603.1, and 1637. Intermec bar code readers and printers are used to provide electronic chain of custody and sampling event information. Logbook entries and "Request for Analysis" forms (maintainea in accordance with separate project procedures) are used to verify bar code information. Bar code reader contents are uploaded daily to the RI/FS Field Operations Facility computer system and into Oracle tables. Data gatherers are required to verify reader contents frequently, and necessary changes are authorized and controlled by use of "Data Base Change Request" forms submitted to the Data Base Manager.

Bechtel's VAX cluster is the centralized storage location for project data; PDCC houses all supportive documentation. Daily backup on all data is performed by the Automation Technology Department, which is responsible for system management. Weekly, all data are copied to magnetic tape and stored off site. System access is controlled by user name/password and by specific directory and file protection levels determined by project staff. Backup and system access control are explained in "Automation Technology Procedures and Standards." Oracle use requires another level of user name/password and specific privileges for table access, again determined by proj:ct staff. Training for each data base management position is defined, administered, and documented according to PP 1120 . The Data Base Manager will identify and control the personnel who have received the proper training and demonstrated competence io modify or make additions to data base tables. 
9

\section{REFERENCES AND PERTINENT PROJECT PROCEDURES}

Dara Base Management Plan for the Remedial Investigation/Feasibility Study at Oak Ridge Narional Laboratory, Bechtel National, $i c$. ORNL/ER/Sub/87-99053/2/R1, Oak Ridge, Tenn.

"Automation Technology Procedures and Standards," Bechtel National, Inc., Oak Ridge, Tenn.

BNI Project Procedure 1120, "Administration of RJ/FS Training"

BNI Project Procedure 1501, "Data Collection, Encoding, and Entry"

BNI Project Procedure 1501.1. "Characterization Data Base"

BNI Project Procedure 1502, "Verification of Existing Data"

B.VI Project Procedure 1603, "Sample Information Management System"

BNl Project Procedure 1603.1, "Intermec 946ú Bar Code Reader User's Procedure"

BNI Project Frocedure 1637, "Field Data Acquisition Documentation" 


\section{DISTRIBUTTION}

1. L. V. Asplund/N. W. Durfo ?

2. L. D. Bates

3. K. W. Cook

4. S. B. Garland II

5. C. D. Goins

6. I. A Hook

7. i. D. Hyde

8. A. J. Kuhaida, Jr.

9. V. Legg

10-11. P. T. Owen

12. G. E. Rymer

13. P. A. Schrandt
14. D. W. Swindle

15-17. L. D. Yoorhees

18. D. R. Watkins

19. R. K. White

20. A S. Will

21-25. ER Document Management Center

26. Central Research Library

27. Laboratory Records Dept.

28. Laboratory Records, ORNL-RC

29. ORNL Patent Section

30. Offixe of Assistant Manager for Energy Research and Development, DOE Field Office, Oak Ridge, P.O. Box 2001, Oak Ridge, TN 37831-8600

31. P. H. Edmonds, Radian Corporation, 120 South Jefferson Circie, Oak Ridge, TN 37830

32-33. J. R. Kannard, Program Manager, Bechtel National, Inc., P.O. Box 350, Oak Ridge Corporate Center, 151 Lafayette Drive, Oak Ridge, TN 3783u

34-37. W. E. Murphie, Department of Energy, Office of Environmental Restoration, Eastern Area D\&D Branch, EM-423 (GTN), Washington, DC 20545

38-39. S. S. Perkins, DOE Field Office, Oak Ridge, Information Resource Center, 105 Broadway, Oak Ridge, TN 37830

40-41. S. P. Riddle, DOE Field Office, Oak Ridge, P.O. Box 2001, Oak Ridge, TN $37831-8541$

42-43. R. C. Sleeman, DOE Fïeld Office, Oak Ridge, P.O. Box 2001, Oak Riage, TN 37831.8541

44-45. Office of Scientific and Technical Information, P.O. Box 62, Oak Ridge, TN 37831 

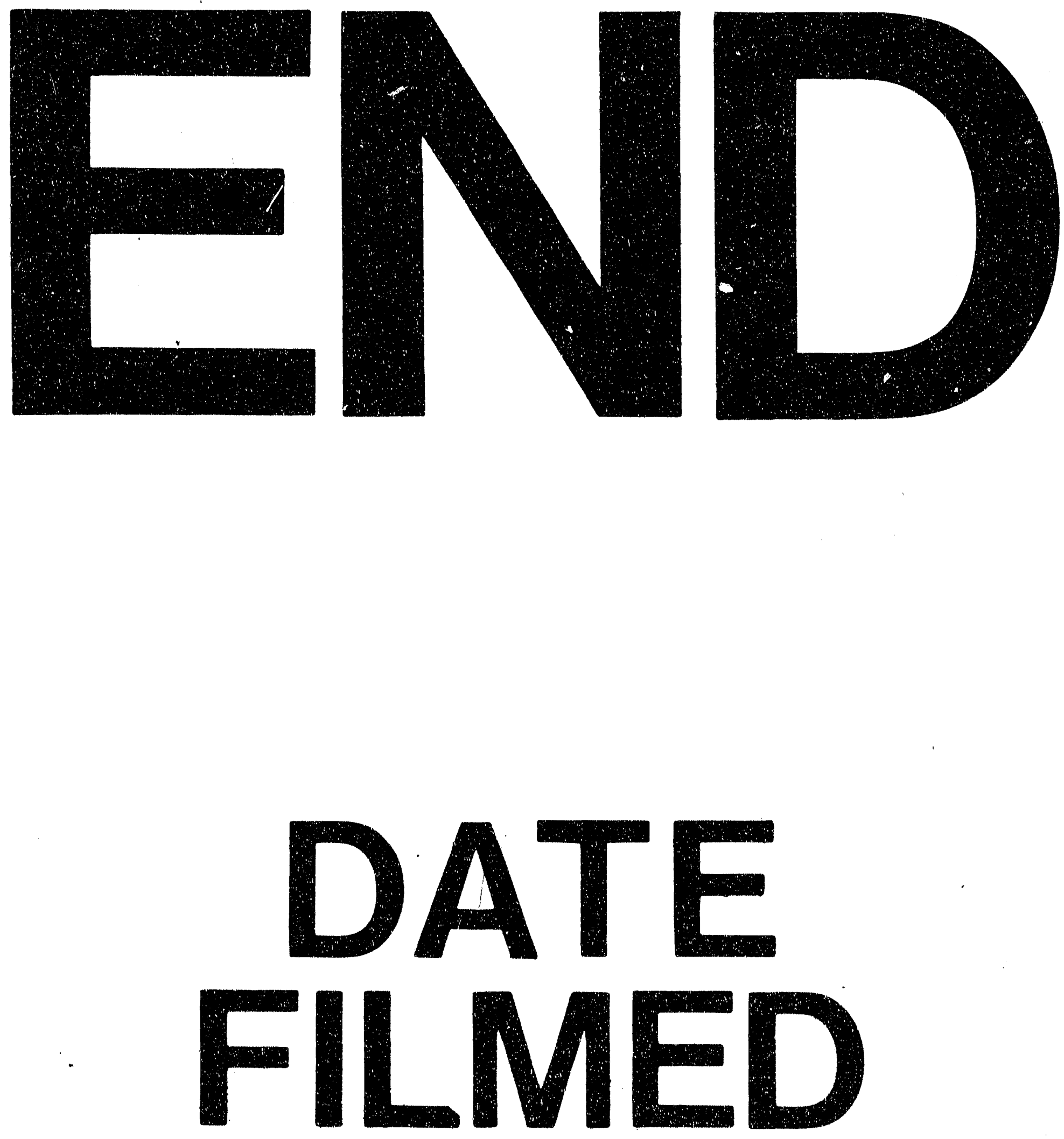

宑

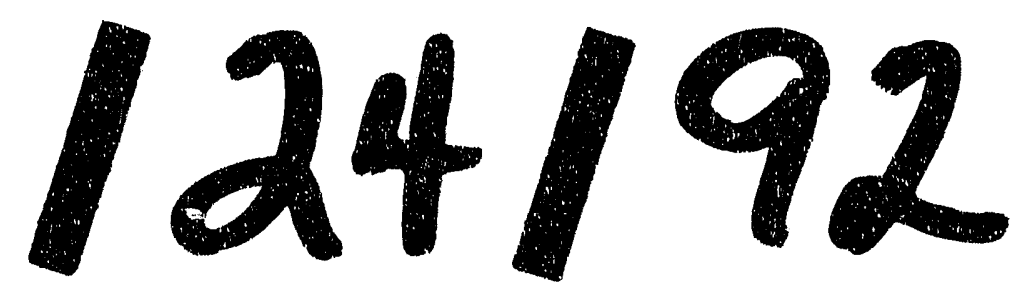




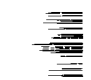

